\title{
Physicochemical analysis of desi yoghurts produced by the local community in Gilgit District
}

\author{
Muhammad Shahnawaz ${ }^{1 \star}$, Saghir Ahmed Sheikh² and Zahid Ali Akbar ${ }^{1}$ \\ ${ }^{1}$ Department of Agriculture and Food Technology, Karakoram International University, Gilgit. \\ ${ }^{2}$ Institute of Food Sciences and Technology, Sindh Agriculture University, Tandojam.
}

Accepted 18 June, 2013

\begin{abstract}
This study was carried out in the Department of Food Technology, Karakoram International University Gilgit, Pakistan. The desi yoghurt samples were collected from various narrow villages of Gilgit District. The desi yoghurt is prepared with pure cow milk by a hygienic and organic process. Results indicate that yoghurt of Oshikandas showed high moisture content and total soluble solids; whereas, Gilgit town yoghurt showed low moisture content and high titratable acidity. Likewise, Danyoure yoghurt showed low total soluble solids as compare to other yoghurts. This study concludes that Gilgit town yoghurt is recommended to be followed for manufacturing since its shelf life is high due to having low moisture content than other two, furthermore; these yoghurts are as per standard of high quality. Yoghurt being nutritious, having healing characteristics and curing gastro intestinal problems, is very beneficial for human's health. Therefore, uses of yoghurt may be considered mandatory in the daily diet.
\end{abstract}

Key words: Desi yoghurt, different villages, Gilgit-Baltistan.

\section{INTRODUCTION}

Yoghurt is a fermented milk product. The word yoghurt originates from Turkish word 'Yogen' meaning thick. Yoghurt is a partially solid fermented milk product which originated centuries ago in Bulgaria. Its attractiveness has grown and is at this time used in most parts of the world (Lee and Lucey, 2010). It is one of the most unique dairy products (Ebenezer and Vedamuth, 1991). Yoghurt is considered highly nutritious for having significant concentration of $\mathrm{Ca}++$ and many other bioactive compounds to carry probiotics to the lower part of the intestine, which can significantly influence the intestinal microflora (Coisson et al., 2005). Preservation of milk by lactic acid bacterial through the acidification process is being practiced since centuries and use of different starter cultures, manufacturing techniques and milk types considerably change the characteristics of fermented milk products (Thapa, 2000). Under normal milk processing industry, special lactic starter cultures are used to ferment milk during preparation range of fermented dairy products (Tamime and Robinson, 1999). Quality and shelf life of fermented dairy products greatly depends upon the quality of raw milk, low total bacterial counts, absence of antibiotics and bacteriophages (Thapa, 2000).

The quality of industrial yoghurt can vary up to some extent due to difference in chemical composition of yoghurt milk, manufacturing process and distribution. Technology of yoghurt, microbiology of starter culture and quality appraisal is the prime importance of any type of yoghurt (Yadav et al., 1993). Yoghurt is highly nutritious and an easily palatable diet due to the predigested nutrients by bacterial starters. It is perishable in view of its unused lactose content (Durga et al., 1986). There is an apparent need for a valuable preservation method to control acid-tolerant spoilage yeasts and molds 
Table 1. Determination of percent chemicl characteristics.

\begin{tabular}{lcccc}
\hline Sample & Moisture & pH & Acidity & TSS \\
\hline Gilgit yoghurt (S1) & $79.5 \mathrm{C}$ & $5.3 \mathrm{~A}$ & $0.81 \mathrm{~A}$ & $12.6 \mathrm{~B}$ \\
Danyour yoghurt (S2) & $80.2 \mathrm{~B}$ & $5.29 \mathrm{~A}$ & $0.75 \mathrm{~B}$ & $11.3 \mathrm{C}$ \\
Oshikandas yoghurt (S30 & $81.5 \mathrm{~A}$ & $4.91 \mathrm{~B}$ & $0.68 \mathrm{C}$ & $13.7 \mathrm{~A}$ \\
\hline
\end{tabular}

*Means followed by same letter in a column are not significantly different at 0.05 .

in yoghurt. Micotoxigenic fungi and pathogenic bacteria are able to grow at refrigeration temperature to numbers, which can result in an infection (Potter and Hotchkiss, 1995). Physical properties of yoghurt are changed by milk ingredients and manufacturing conditions, variables affect physical properties such as heat treatment which apply to milk, acidity, additives, protein content, culture, homogenization mechanical handling of coagulum and presence of stabilizers (Rasic and Kurman, 1978). Changes in the chemical, physical and microbiological composition of yoghurt determine the storage and shelf life of the product (Sofu and Ekinci, 2007). Keeping in view the importance of yoghurt and variable manufacturing processes, this study was conducted to access the physicochemical characteristics of desi yoghurt made from cow milk either meeting the international standard of yoghurt or not.

\section{MATERIALS AND METHODS}

\section{Determination of moisture content}

The moisture content was determined according to AOAC (2000). In this regard, the sample materials were taken in a flat-bottom dish (pre-weighed) and kept overnight in an oven at 100 to $110^{\circ} \mathrm{C}$ and weighed. The loss in weight was regarded as a measure of moisture content which was calculated by the following formula.

$$
\text { Moisture }(\%)=\frac{\text { Weight of fresh sample }- \text { Weight of dry sample }}{\text { Weight of fresh sample }} \times 100
$$

\section{Determination of titratable acidity}

Titratable acidity as tartaric acid was determined according to the method of AOAC (2000). Each sample of the products was treated with $0.1 \mathrm{~N} \mathrm{NaOH}$ solution using titration kit; of which three to five drops of phenolphthalein indicator were used. The volume of alkali used was noted and calculated using following formula.

$$
\text { Titratable acidity }(\%)=\frac{1 \times \text { Eq. Wt. of acid } \times \text { Normality of } \mathrm{NaOH} \times \text { titer } \times 100}{10 \times \text { Weight of sample }(\mathrm{g})}
$$

\section{Determination of TSS}

The total soluble solids (TSS) were determined as per method described by Mazumdar and Majumder (2003) using Digital-Bench-
Refrectometer. Before use, the instrument was cleaned and adjusted to zero at $20^{\circ} \mathrm{C}$ using distilled water. An appropriate quantity of sample of each product prepared was placed on the prism-plate of the refractometer with the help of a glass rod and folding back the cover. For each sample, the instrument was calibrated using distilled water. The reading appeared on the screen was directly recorded as total soluble solids as brix.

\section{Determination of $\mathrm{pH}$}

For determination of $\mathrm{pH}$ (hydrogen ion concentration) in the products, a method of AOAC (2000) was adopted and digital $\mathrm{pH}$ meter was used. Sample solution was taken in the beaker and directly inserted the electrode into the solution. When the first reading was completed, the electrode was wiped with distilled water and dried-up with tissue paper. Similarly, as a continue series, all other samples were determined accordingly.

\section{RESULTS AND DISCUSSION}

In Table 1, results at column one show that Oshikandas yoghurt has comparatively higher moisture content $(81.5 \%)$ whereas Gilgit yoghurt has lower moisture content $(79.5 \%)$. The results are in agreement with Ammara and Imran (2010) who analyzed the moisture content during storage by using different starter cultures and recorded 84.66, 85.32, 85.16, 86.29, 86.22 and $86.40 \%$. pH of Gilgit, Danyour and Oshikandas yoghurts were 5.30, 5.29 and 4.91, respectively. Gilgit yoghurt has high $\mathrm{pH}$ value as compared to Danyour and Oshikandas yoghurts. Our results relatively correspond to Rodrigues et al. (2010) who concluded that pH of yoghurt is 4.30 to 5.08. The low $\mathrm{pH}$ of yoghurt is due to environment for the growth of acid tolerant yeasts and molds (Banaquio et al., 1981; Spillmann and Geiges, 1983). Furthermore, results indicate that mean acidity of all three yoghurt is $0.75 \%$. However, comparatively, Oshikandas yoghurt has the lower acidity, whereas Gilgit yoghurt has higher acidity. This result is also in agreement with Younus et al. (2002) who analyzed the quality evaluation of market yoghurt/dahi and recorded $0.89,0.87$ and 1.13 titratable acidity. Our findings are also in accordance with the findings of Saleh et al. (2007) who concluded that the titratable acidity of stirred yoghurt is 0.93 . Likewise, TSS was determined as 12.6, 11.3 and 13.7 brix for Gilgit, Danyour and Oshikandas yoghurts, respectively. To show whether TSS of these three yoghurts meets the 
standard or not, another study was reviewed (Zekai, 2003) which is agreement to $d$ value of TSS found (14.58 Brix)

\section{Conclusion and recommendation}

From the research it is concluded that the Oshikandas yoghurt has high moisture content and total soluble solids. The Gilgit yoghurt has low moisture content but high titrable acidity; while Danyoure yoghurt have low total soluble solids as compared to other yoghurts. Thematically, all three yoghurts are strongly recommended to be used because these yoghurts have all quality characteristics of international standard. Yoghurt being nutritious, having healing characteristics and curing gastro intestinal problems is very beneficial for human's health.

\section{REFERENCES}

Ammara K, Imran P (2010). Determination of moisture content in stored yoghurt with different starter culture. Pak. J. Nutr. 20(2):221-227.

Banaquio VL, Publico CB, Calisay OG (1981). Keeping quality of yogurt. Philippine 1. Biol. 10(1):109-112.

Coisson JD, Travaglia F, Piana G, Capasso M, Arlorio M (2005). Euterpeoleracea juice as a functional pigment for yogurt. Food Res. Int. 38:893-897.

Durga LC, Sharda D, Sastry MP (1986). Effect of storage conditions on keeping riboflavin and niacin of plain and fruit yoghurt. Indian J. Dairy Sci. 39(4):404-409.

Lee WJ, Lucey JA (2010). Formation and Physical Properties of Yogurt. Asian-Aust. J. Anim. Sci. 23(9):112 -1136.

Mazumdar BC, Majumder K (2003). Methods on physico-chemical analysis of fruits. Practical Manual Book. Metropolitan New Delhi, India. neural network modeling. J. Dairy Sci. 90(7):3118-3125.

Mohammed Saleh, Khursheed Ahmed, Taws Khan (2007). Effect of wheat germ and wheat bran on the fermentation activity, phytic acid content and colour of tarhana, a wheat flour-yoghurt mixture. J. Food Eng. 78(2):681-686.

Potter NF, Hotchkiss JH (1995). Food Science $5^{\text {th }}$ Edition, Chapman and Hall (Routledge), Florence, KY.quality, riboflavin and niacin of plain and fruit yoghurt. Indian J. Dairy Sci. 39(4): 404-409.

Rasic J, Kurmann JA (1978). Yoghurt: Scientific Grounds ,Technology Report of the FAO E-mail conference on small-scale milk collection and processing in developing countries.
Sofu A, Ekinci FY (2007). Estimation of storage time of yogurt with artificial neural network modeling. J. Dairy Sci. 90(7):3118-25.

Rodrigues LA, Ortolani MBT, Nero LA (2010). Microbiological quality of yoghurt commercialized in Viçosa, Minas Gerais, Brazil. Afr. J. Microbiol. Res. 4(3):210-213.

Spillmann DK, Geiges M (1983). Recent Trends in Development of Fermented Milks. Curr. Nutr. Food Sci. 3:91-108.

Thapa TB (2000). Small - scale milk processing technologies. Discussion paper. 23(9):1127-1136.

Yadav JS, Grover S, Batish VK (1993). A Comprehensive dairy microbiology. Metropolitan New Delhi, India.

Younus S, Tariq M, Tariq A (2002). Quality Evaluation of Market Yoghurt /Dahi. Pak. J. Nutr. 1(5):226-230.

Zekai T (2003). Studies on effect of different varieties of date palm paste incorporation on quality characteristics of yoghurt. Carpathian J. Food Sci. Technol. 3(1):28-38. 